\title{
Chemical composition of phytoplankton from the estuaries of Eastern Amazonia
}

\author{
Maria do Perpetuo Socorro Progene VILHENA ${ }^{1}$, Marcondes Lima da COSTA², José Francisco BERREDO ${ }^{*}$, \\ Rosildo Santos PAIVA 4 , Pryscila Denise ALMEIDA ${ }^{5}$ \\ 1 Universidade Federal do Pará. Instituto de Ciências Exatas e Naturais, Programa de Pós-Graduação em Química. Av. Augusto Corrêa, 01 CEP: 66075-110, Guamá, Belém-Pará, Brasil. \\ 2 Universidade Federal do Pará. Instituto de Geociências. Av. Augusto Corrêa, 01 CEP: 66075-110, Guamá, Belém-Pará, Brasil. \\ $3^{*}$ Museu Paraense Emilio Goeldi. Coordenação de Ciência da Terra e Ecologia. Av. Perimetral, 1901. CEP: 66077-530, Terra Firme, Belém-Pará, Brasil. \\ ${ }^{4}$ Universidade Federal do Pará. Instituto de Ciências Biológica. Av. Augusto Corrêa, 01 CEP: 66075-110, Guamá, Belém-Pará, Brasil. \\ 5 Instituto de Botânica de São Paulo. Pós-Graduação em Biodiversidade Vegetal e Meio Ambiente, Av. Miguel Stéfano, 3687, São Paulo, Brasil. \\ * Corresponding author: berredo@museu-goeldi.br
}

\section{ABSTRACT}

Phytoplankton is important bioindicator of chemical and biological modifications of natural ecosystems. The objective of this study was to determine the total chemical composition of the phytoplankton of the Pará and Mocajuba estuaries on the eastern coast of the Amazon region in the Brazilian state of Pará. The chemical composition of the surface water, bottom sediments (total sample and bioavailable fraction), and the phytoplankton were determined by inductively coupled plasma optical emission spectrometry. Phytoplankton contained high concentrations of $\mathrm{Ca}, \mathrm{P}, \mathrm{Mn}, \mathrm{Fe}, \mathrm{Zn}, \mathrm{Al}, \mathrm{Ba}$, and $\mathrm{Pb}$. The phytoplankton of the Mocajuba estuary is rich in Fe (2,967-84,750 $\left.\mathrm{g} \mathrm{g}^{-1}\right)$, while those from the Pará is rich in $\mathrm{Al}\left(1,216-15,389 \mu \mathrm{gg}^{-1}\right)$, probably reflecting divergent anthropogenic inputs. Both samples indicated a high bioconcentration factor derived from both the water and the bioavailable fraction, reflecting the efficiency of these organisms in the concentration of metals.

KEYWORDS: Sediments, trace metals, plankton, surface water

\section{Composição química do fitoplâncton de estuários da Amazônia oriental}

\section{RESUMO}

O fitoplancton é de grande importância para os estudos das interações solo-água, como indicadores de modificaçóes químicas e biológicas nos ecossistemas naturais. $\mathrm{O}$ objetivo desse estudo foi determinar a composiçáo química total do fitoplâncton nos estuários do rio Pará e Mocajuba (Pará, Brasil). As análises químicas foram realizadas na água superficial, sedimento de fundo (amostra total e fração biodisponível) e no fitoplancton, por espectrometria óptica e de massa com plasma indutivamente acoplado. A composição química elementar do fitoplancton é composta por elevadas concentraçóes de Ca, P, Mn, Fe, Zn, Al, Ba e Pb. O fitoplancton do estuário do rio Mocajuba é rico em Fe (2.967 a $\left.84.750 \mu \mathrm{g} \mathrm{g}^{-1}\right)$ e do rio Pará rico em Al (1.216 a 15.389 $\mu \mathrm{g} \mathrm{g}^{-1}$ ), provavelmente com contribuição antropogênica. O material fitoplanctonico apresentou elevado fator de bioconcentração proveniente tanto da água quanto da fração biodisponível, e reflete a eficiência desses organismos em concentrar metais.

PALAVRAS-CHAVE: Sedimentos, metais-traço, fitoplancton, água superficial 


\section{INTRODUCTION}

Rivers are the principal routes of transport of dissolved and particulate matter from inland areas to the oceans. This matter may be assimilated by planktonic organisms, which are one of the key components of the trophic dynamics of estuarine ecosystems (Furuya 1990; Kjerfve and Lacerda 1993). Bioactive metals in river water strongly influence the production and the chemical composition of the phytoplankton (Bruland et al. 1991) and may also affect cell structure and internal enzymatic activities (Viarengo 1985; Magdaleno et al. 1997). Phytoplankton may thus concentrate large quantities of chemicals in their structure (Martin and Knauer 1973), and each taxon or population may be metabolically distinct, depending on the specific chemical elements they have accumulated (Sigee et al. 1998). Given their short life cycle and sensitivity to environmental impact, phytoplankton provide an ideal model for the study of soilwater interactions, and can be used to identify and describe modifications in the physiological, biochemical, and ecological processes that occur in natural ecosystems (Gonzalez-Davila 1995; Petersen and Gustavson 1996; Luoma et al. 1998).

Data on the chemical composition of phytoplankton found in the shallow waters of the Amazon coast are rare, possibly due to their small size and the technical difficulties of preparing specimens. Amazonian phytoplankton studies have tended to focus on taxonomy or on explaining the high diversity and densities of phytoplankton found in the region (Figueiras and Pazos 1991; Leynaert et al. 1991; Paiva et al. 2006). The objective of this study was to determine the total chemical composition of the phytoplankton of the Pará and Mocajuba estuaries on the eastern coast of the Amazon region in the Brazilian state of Pará.

\section{MATERIALS AND METHODS}

\section{Study areas}

Sampling took place in two estuaries east of the mouth of the Amazon River, in the northeast of the state of Pará: the Mocajuba River is strongly influenced by the marine environment, while the Pará River is primarily influenced by fluvial dynamics. Furthermore, while the Mocajuba estuary is relatively well preserved, the Pará estuary is subject to a variety of anthropogenic impacts derived from the transportation of bulk cargoes such as mineral ores, fuel oils, and caustic soda related to the activities of local industries (Albras, Alunorte, Imerys rio Capim and Pará Pigmentos) and from the busy Vila do Conde shipping terminal (Figure 1, A and B).

The two estuaries have a similar tropical climate, characterized by intense rainfall (mean annual precipitation of $3000 \mathrm{~mm}$ ), heat (mean temperature $27.7^{\circ} \mathrm{C}$ ), and humidity (typically between 80 and $85 \%$ ). Rainfall is most intense between January and June, and contributes to the run-off of organic and inorganic detritus, and the discharge of freshwater into the estuaries. During the dry season (August-November) freshwater discharge decreases considerably, resulting in an influx of oceanic water, although this process is relatively weak in the Pará estuary.

The geology of the study region is characterized by lateritized clastic sedimentary rocks (mudrocks and sandstones) of the Miocene-Pliocene Barreiras Formation, as well as Quaternary sediments represented by beaches, dunes and paleodunes, swamps, saltmarshes, coastal and muddy tidal plains, sandbanks and mud flats, as well as alluvial deposits (Costa et al. 2004; Siva et al. 2009).

The vegetation of the Mocajuba estuary is dominated by secondary forests on latosols, and mixed mangrove forests composed of Rhizophora mangle and Avicennia germinans on the tidal plains (Silva et al. 2009). By contrast, the Pará estuary is more typical of a lower Amazon floodplain, with freshwater swamps dominated by Euterpe oleracea and Mauritia flexuosa palms, and in particular Montrichardia arborescens Schott (Macedo et al. 2005).

Samples of water, sediments, and phytoplankton were collected in each estuary in January, April, August, and November, 2011. The samples were obtained at three points (P1C, P2C, and P3C) in the Mocajuba estuary (Figure 1A), and four (P1B, P2B, P3B, and P4B) points in the Pará (Figure 1B).

Surface water samples were collected during both the flood and ebb tides, and stored in one-liter polyethylene bottles before being vacuum-filtered through an acetate filter with a porosity of $0.45 \mu \mathrm{m}$. The samples were stored in nitric acid at $\mathrm{pH}<2$ for the measurement of dissolved chemical elements. Physico-chemical and chemical parameters $(\mathrm{pH}$, salinity, temperature, and nitrate concentrations) were measured in situ using a (Horiba W-23XD multi-probe Kyoto, Japan). The sediment samples were collected with a stainless steel Petersen-type bottom grab, maintained under refrigeration $\left(4{ }^{\circ} \mathrm{C}\right)$ before being dried to a constant weight in a stove at $50{ }^{\circ} \mathrm{C}$, and then macerated in an agate mortar.

Phytoplankton was collected in horizontal trawls at a depth of $50 \mathrm{~cm}$ during the flood tide, using a standard plankton net with a $64 \mu \mathrm{m}$ mesh (this mesh size is needed due to the strong local hydrodynamics). The wet samples were then sieved and passed through a $20 \mu \mathrm{m}$ mesh before being washed with distilled water. Each sample was examined under a binocular microscope (Zeiss SV6 Binocular Stereomicroscope, Goettingen, Germany) to remove residues (e.g., leaves, stalks, and shells), and then lyophilized (Labconco, Freeze Dry Systems, 7752000, Kansas City, Missouri).

Subsamples $(250 \mathrm{~mL})$ of the plankton were fixed in a $4 \%$ formaldehyde solution and identified to the species level using 


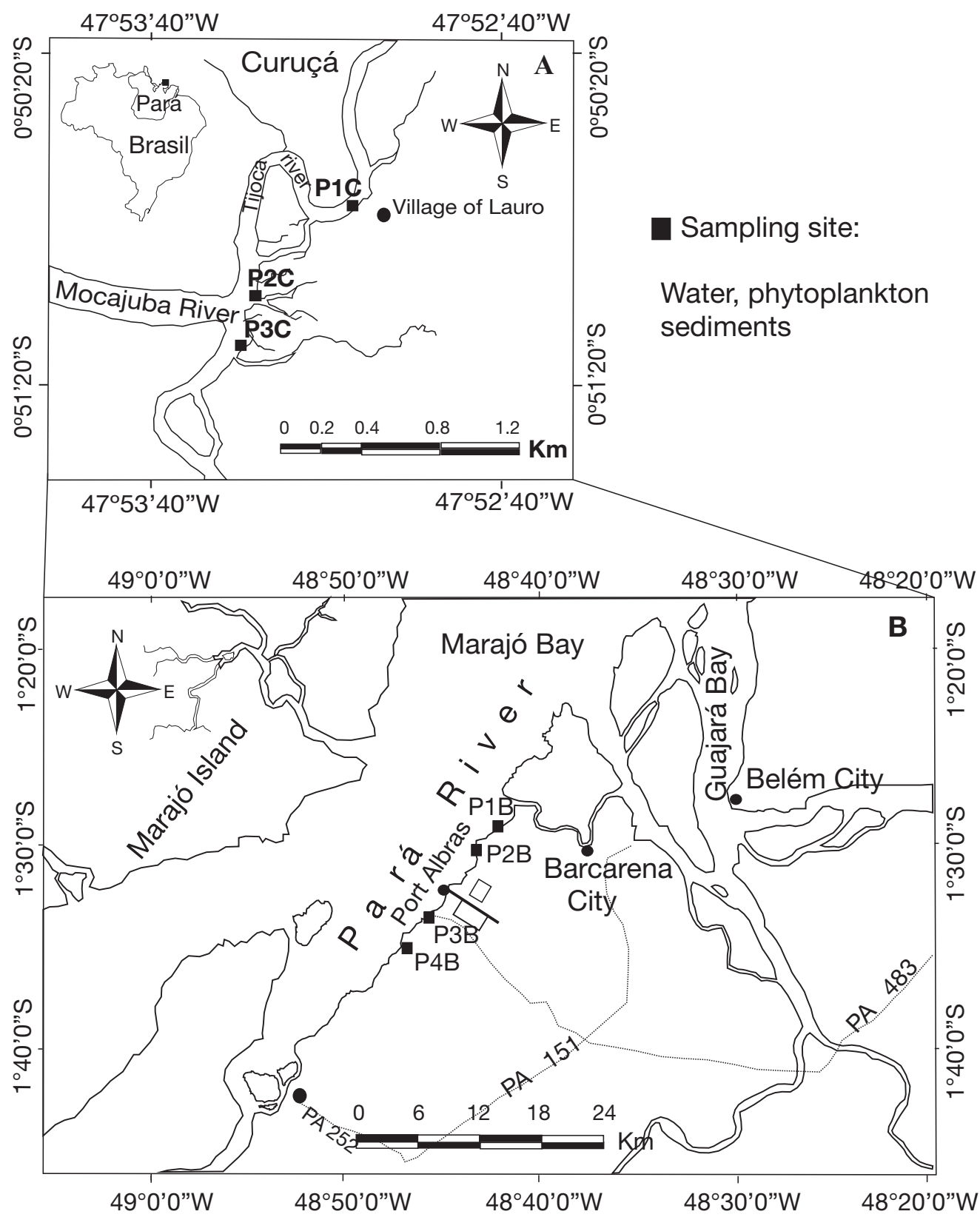

Figure 1. Location of the sampling points in the two study areas

the specialized literature for each taxonomic group. Density was measured as the number of organisms per liter of water (Utermöhl 1958). Samples were analyzed under an (Olympus IX70 inverted microscope, New York USA).

The mineralogy of the sediment was determined by X-ray diffraction at the Institute of Geosciences, Federal University of Pará, using a diffractometer (PW 3040, PANalytical, Almelo, The Netherlands), with a copper anode $(\mathrm{k} \alpha 1=$ $1.54060 \AA$ ) , tension generator and current adjusted to $40 \mathrm{kV}$ and $30 \mathrm{~mA}$, respectively. Diffractions of total samples ranged from 5 to $75^{\circ} 2 \theta$, with step size of $0.02^{\circ}-10 \mathrm{~s}$. The results were interpreted using the X'Pert HighScore 2.1 software and the International Center for Diffraction Data database.

The images for micromorphological observations, textural, and semi-quantitative chemical analyses were obtained using a Scanning Electron Microscope, SEM (LEO 1450, London, England) coupled to an Energy Dispersive X-ray Spectroscope (EDS) 500 DP, Greshram Scientific Instruments (Sirus 10/7.5, 
London, England). The phytoplankton samples were placed in an aluminum holder, at a controlled temperature and metalized with gold. These analyzes were conducted in the Goeldi Museum laboratory in Belém, Brazil.

The total chemical analysis of the bottom and suspended sediments was based on the alkaline fusion of the samples with lithium metaborate/tetraborate, followed by solubilization with nitric acid. Finally, measurements were made by mass inductively coupled plasma mass spectrometry (ICP-MS) in the Acme Analytical Laboratory, Vancouver, Canada, following the Litho-Geochemical Standard Package codes and STD OREAS45CA reference materials. The bioavailable fraction of the major and trace chemical elements in the sediments was extracted by leaching with $0.1 \mathrm{~N} \mathrm{HCl}$ under continuous agitation (16 hours) and measured by ICP-MS in the Acme Analytical Laboratory.

The concentrations of major and trace chemical elements in the water were also determined by ICP-MS in the Acme Laboratory, using the equipment specified above and STD TMDA-70 reference materials. The phosphate concentrations in the water were determined by the ammonium molybdate and silica method, with ammonium heptamolybdate, using a (Spectro Vision UV-VIS, DB-1880S, Shanghai, China) at $835 \mathrm{~nm}$ in the Goeldi Museum Laboratory in Belém.

The phytoplankton was analyzed by digesting $0.1 \mathrm{~g}$ (dry weight) subsamples in $\mathrm{HNO}_{3}$ and $\mathrm{HCl}(3: 1 \mathrm{v} / \mathrm{v})$. This solution was then heated to $100^{\circ} \mathrm{C}$ for 45 minutes until completely digested. Once cooled, samples were measured with Milli-Q water. The concentrations of $\mathrm{Na}, \mathrm{K}, \mathrm{Ca}, \mathrm{Mg}, \mathrm{P}, \mathrm{Mn}, \mathrm{Fe}, \mathrm{Cu}$, $\mathrm{Zn}, \mathrm{Se}, \mathrm{Al}, \mathrm{As}, \mathrm{Ni}, \mathrm{Cd}, \mathrm{Ba}$ and $\mathrm{Pb}\left(\mathrm{gg} \mathrm{g}^{-1}\right)$ were obtained by inductively coupled plasma optical emission spectrometry (ICP-OES, HORIBA, Jobin Yvan Ultima 2, Kyoto, Japan), in the Laboratory for Environmental Analysis and Geoprocessing Laboratory at the Brazilian Center for Nuclear Energy in Agriculture (CENA/USP) in Piracicaba. The accuracy was evaluated using Dogfish Muscle Certified Reference Material (DORM-2). The chemical concentration of each element in each sample was obtained from the arithmetic mean of the samples in triplicate. The blanks were prepared with the same quantities of reagents used in the chemical analyses and the same reference material, in order to assure the integrity of the digestive process. The recuperation of the certificated samples ranged from $92 \%$ to $102 \%$ for $\mathrm{Na}, \mathrm{K}, \mathrm{Ca}, \mathrm{Mg}, \mathrm{P}, \mathrm{Mn}, \mathrm{Fe}$, $\mathrm{Cu}, \mathrm{Zn}, \mathrm{Se}, \mathrm{Al}, \mathrm{Ni}, \mathrm{As}$, and $\mathrm{Ba}$, and $88 \%$ for $\mathrm{Cd}$ and $\mathrm{Pb}$. The detection limits were $0.01 \mathrm{\mu g} \mathrm{g}^{-1}$ for $\mathrm{Na}, \mathrm{K}, \mathrm{Ca}, \mathrm{Mg}, \mathrm{P}, \mathrm{Mn}$, $\mathrm{Fe}, \mathrm{Cu}, \mathrm{Zn}, \mathrm{Cd}$, and $\mathrm{Ba}, 0.02 \mu \mathrm{g} \mathrm{g}^{-1}$ for $\mathrm{Ni}, \mathrm{Se}$, and $\mathrm{As}$, and $0.04 \mu \mathrm{g} \mathrm{g}^{-1}$ for $\mathrm{Pb}$ and $\mathrm{Al}$.

The bioconcentration factor (BCF) for the phytoplankton represents the ratio between the concentration of chemical elements in the phytoplankton biomass (dry weight in $\mu \mathrm{g}$ $\left.\mathrm{g}^{-1}\right)$ and the concentration of these elements in the water $(\mu \mathrm{g}$
$\mathrm{mL}^{-1}$ ). The sediment bioconcentration factor (BSCF) is the ratio between the total chemical concentration in the sediment and the bioavailable fraction (dry weight in $\mu \mathrm{g} \mathrm{g}^{-1}$ ) following Kenaga (1980). The concentrations of trace elements in the phytoplankton were normalized by the concentrations of the phosphate ion ( $\mu \mathrm{g} \mathrm{mL}^{-1}$ trace element: $\mu \mathrm{g} \mathrm{mL}^{-1}$ phosphate), and the chemical concentrations of the sediments were normalized by the phosphorus ( $\mu \mathrm{g} \mathrm{g}^{-1}$ trace element: $\mu \mathrm{g} \mathrm{g}^{-1}$ $\mathrm{P})$. The BCF and BSCF values are expressed as logarithms. A linear regression analysis was used to quantify the relationships between the concentrations of trace elements in the water and the $\mathrm{BCF}$ (significance level $\mathrm{p}=0.05$ ). A principal coordinates analysis (PCoA) was run in PC-ORD, version 6.0 (McCune and Mefford 2011), using the logarithmic $[\log (x+1)]$ data.

\section{RESULTS}

\section{Bottom sediments}

The silt/clay sediments of the Mocajuba estuary have predominant mineralogical composition of quartz and kaolinite with lesser concentrations of smectite and illite. The levels of $\mathrm{SiO}_{2}, \mathrm{Al}_{2} \mathrm{O}_{3}$ and $\mathrm{Fe}_{2} \mathrm{O}_{3}$ in these sediments were high, as were those of $\mathrm{Na}_{2} \mathrm{O}, \mathrm{K}_{2} \mathrm{O}, \mathrm{MgO}$, and $\mathrm{CaO}$. In general, the concentrations of trace elements were close to or below mean UCC (Upper Continental Crust) levels, with the exception of $\mathrm{Cr}$ and As (Table 1).

In the Pará estuary, the predominantly sand/silt sediments are primarily composed of quartz, and to a lesser extent, kaolinite, illite, goethite, and hematite. The concentrations of $\mathrm{SiO}_{2}$ were high, with low concentrations of $\mathrm{Al}_{2} \mathrm{O}_{3}$ and $\mathrm{Fe}_{2} \mathrm{O}_{3}$, with $\mathrm{Na}_{2} \mathrm{O}, \mathrm{K}_{2} \mathrm{O}, \mathrm{MgO}$, and $\mathrm{CaO}(<0,5 \%)$. The concentrations of trace elements were below UCC levels (Table 1). The concentrations of the bioavailable elements were higher for $\mathrm{Na}, \mathrm{K}, \mathrm{Ca}, \mathrm{Mg}, \mathrm{Fe}, \mathrm{Al}$, and $\mathrm{Ba}$, although these values are still extremely low $(<1 \%)$ when compared to the total chemical composition of the sediments (Table 1).

\section{Surface waters}

The waters of the Mocajuba estuary are slightly acid ( $\mathrm{pH}$ 6.26.9) and strongly enriched with alkalis $\left(\mathrm{Na}^{+}>\mathrm{Mg}^{2+}>\mathrm{Ca}^{2+}>\mathrm{K}^{+}\right)$, with high levels of $\mathrm{Cl}^{-}$and $\mathrm{Br}$. Relatively high concentrations of most chemical elements, such as $\mathrm{Fe}, \mathrm{Zn}, \mathrm{Se}, \mathrm{Sr}, \mathrm{Pb}$ and $\mathrm{Al}$, were recorded in the samples (Table 2).

The Pará estuary had a $\mathrm{pH}$ of between 5.8 and $7.8, \mathrm{Na}^{+}$ (0.16-1,172 $\left.\mathrm{mmol} \mathrm{L}^{-1}\right)$ and low concentrations of $\mathrm{Ca}^{2+}$, $\mathrm{Mg}^{2+}$ and $\mathrm{K}^{+}\left(<0.13 \mathrm{mmol} \mathrm{L}^{-1}\right)$. These waters were relatively rich in $\mathrm{Fe}$ and $\mathrm{Al}$ (Table 2). During the dry season (AugustNovember), the mean concentrations of the chemical elements were higher than those recorded in the rainy season (January and April). The concentrations of the principal nutrients (phosphates, silicates, and nitrates) in the water were also higher during the dry season. 
Table 1. Chemical composition (means and standard deviations in percentage weight) and trace elements (in $\mu \mathrm{g} \mathrm{g}^{-1}$ ) of the bottom sediments of the Pará river and Mocajuba river estuaries and Upper Continental Crust - UCC (Taylor and McLennan 1985)

\begin{tabular}{|c|c|c|c|c|c|}
\hline & \multicolumn{2}{|c|}{ Pará River } & \multicolumn{2}{|c|}{ Mocajuba River } & \multirow[b]{2}{*}{ UCC } \\
\hline & Total sample & $\begin{array}{c}\text { Bioavailable } \\
\text { fraction }\end{array}$ & Total sample & $\begin{array}{c}\text { Bioavailable } \\
\text { fraction }\end{array}$ & \\
\hline $\mathrm{SiO}_{2}$ & $85.2 \pm 11.42$ & 0.001 & $57.37 \pm 11$ & 0.003 & 66 \\
\hline $\mathrm{Al}_{2} \mathrm{O}_{3}$ & $5.46 \pm 5.06$ & 0.001 & $15.26 \pm 2.85$ & 0.002 & 15 \\
\hline $\mathrm{Fe}_{2} \mathrm{O}_{3}$ & $2.4 \pm 1.48$ & 0.002 & $4.96 \pm 1.01$ & 0.010 & 4.3 \\
\hline $\mathrm{MnO}$ & $0.02 \pm 0.01$ & 0.0001 & $0.02 \pm 0.00$ & 0.001 & 0.07 \\
\hline $\mathrm{Na}_{2} \mathrm{O}$ & $0.13 \pm 0.09$ & 0.0006 & $1.21 \pm 0.60$ & 0.002 & 3.9 \\
\hline K20 & $0.45 \pm 0.37$ & 0.0002 & $1.47 \pm 0.23$ & 0.001 & 3.4 \\
\hline $\mathrm{CaO}$ & $0.13 \pm 0.11$ & 0.002 & $0.28 \pm 0.13$ & 0.003 & 2.2 \\
\hline $\mathrm{MgO}$ & $0.21 \pm 0.20$ & 0.0002 & $1.4 \pm 0.40$ & 0.003 & 4.2 \\
\hline $\mathrm{P}_{2} \mathrm{O}_{5}$ & $0.13 \pm 0.01$ & 0.0001 & $0.2 \pm 0.02$ & 0.001 & \\
\hline $\mathrm{Ni}$ & $20 \pm 0.00$ & 0.01 & $22.4 \pm 3.15$ & 0.02 & 20 \\
\hline $\mathrm{Cr}$ & $30.2 \pm 19.3$ & 0.01 & $50 \pm 30.05$ & 0.03 & 35 \\
\hline $\mathrm{Cu}$ & $4.2 \pm 3.65$ & 0.02 & $7.6 \pm 2.11$ & 0.05 & 25 \\
\hline $\mathrm{Zn}$ & $14 \pm 11$ & 0.56 & $28.4 \pm 7.78$ & 0.81 & 71 \\
\hline As & $1.5 \pm 0.71$ & 0.01 & $9.33 \pm 2.53$ & 0.05 & 1.5 \\
\hline Se & $0.5 \pm 0.10$ & 0.0005 & $0.5 \pm 0.10$ & 0.00 & \\
\hline $\mathrm{Sr}$ & $21 \pm 15$ & 0.12 & $87.38 \pm 27$ & 0.31 & 350 \\
\hline $\mathrm{Cd}$ & $<0.10$ & 0.0002 & $<0.10$ & 0.00 & 0.09 \\
\hline $\mathrm{Ba}$ & $133 \pm 93$ & 2.19 & $210 \pm 54$ & 0.72 & 550 \\
\hline $\mathrm{Pb}$ & $4 \pm 2.58$ & 0.01 & $12 \pm 2.75$ & 0.10 & 20 \\
\hline
\end{tabular}

\section{Phytoplankton}

The microphytoplankton community is more diverse in the Mocajuba estuary, with a total of 126 taxa, $85 \%$ of which belong to the Bacillariophyceae, $10 \%$ to the Cyanophyceae, $3 \%$ to the Chlorophyceae, $1 \%$ to the Dynophycaea, and $1 \%$ to the order Tintinnidae. Coscinodiscus oculus iridis and $C$. janischii were relatively abundant during the rainy season months, but rarer in May, June, and July. Coscinodiscus was common in most of the months analyzed.

A total of 60 species were found in the Pará estuary, which was dominated by diatoms, in terms of both the number of species and density, especially for the species Actinocyclus normanii, Aulacoseira granulata, Coscinodiscus rothii and Polymyxus coronalis (Figure 2), which are common in the brackish waters of the Amazon region (Paiva 2006). During the drier months, the diversity of algae increased and a number of different taxa became highly abundant, such as Polymixus coronalis, and the genera Aulacoseira and Coscinodiscus. During
Table 2. Chemical composition (means and standard deviations) for cations and anions ${ }^{\mathrm{b}}\left(\mathrm{mmol} \mathrm{L}^{-1}\right)$; $\mathrm{NO}_{3}{ }^{-}, \mathrm{PO}_{4}{ }^{3-}$ and $\mathrm{H}_{4} \mathrm{SiO}_{4}{ }^{a}\left(\mu \mathrm{mol} \mathrm{L}^{-1}\right)$ and trace elements $\left(\mu \mathrm{L} \mathrm{L}^{-1}\right)$ of the surface water and the chemical composition of the phytoplankton (mean values in $\mu \mathrm{g} \mathrm{g}^{-1}$ )

\begin{tabular}{|c|c|c|c|c|}
\hline & \multicolumn{2}{|c|}{ Pará River } & \multicolumn{2}{|c|}{ Mocajuba River } \\
\hline & Freshwater & Phytoplankton & Saltwater & Phytoplankton \\
\hline $\mathrm{H}_{4} \mathrm{SiO}_{4}$ & $166 \pm 156^{a}$ & & $159 \pm 48^{a}$ & \\
\hline $\mathrm{Na}$ & $220 \pm 327^{b}$ & $143 \pm 80$ & $1099 \pm 1149^{b}$ & $2094 \pm 852$ \\
\hline K & $0.03 \pm 0.00^{\mathrm{b}}$ & $1250 \pm 445$ & $3.29 \pm 1.51^{\mathrm{b}}$ & $2118 \pm 272$ \\
\hline $\mathrm{Mg}$ & $0.07 \pm 0.03^{b}$ & $1452 \pm 651$ & $18 \pm 9.51^{b}$ & $2666 \pm 1831$ \\
\hline $\mathrm{Ca}$ & $0.01 \pm 0.04$ & $2029 \pm 1872$ & $3.57 \pm 1.79^{b}$ & $3919 \pm 1732$ \\
\hline$P$ & & $775 \pm 424$ & & $2074 \pm 372$ \\
\hline $\mathrm{Cr}$ & $1 \pm 0.65$ & $16.61 \pm 4.48$ & $198 \pm 138$ & 32 \\
\hline $\mathrm{Mn}$ & $6 \pm 7.04$ & $510 \pm 197$ & $79 \pm 32$ & $1064 \pm 662$ \\
\hline $\mathrm{Fe}$ & $196 \pm 151$ & $21887 \pm 9605$ & $5368 \pm 4810$ & $33435 \pm 26437$ \\
\hline $\mathrm{Cu}$ & $2.26 \pm 0.27$ & $16 \pm 3$ & $43 \pm 37$ & $17 \pm 3$ \\
\hline $\mathrm{Zn}$ & $11 \pm 6.81$ & $38 \pm 25$ & $164 \pm 140$ & $102 \pm 55$ \\
\hline Se & $1 \pm 0.05$ & $1.4 \pm 1.2$ & $1638 \pm 1500$ & $1.8 \pm 1.1$ \\
\hline $\mathrm{Sr}$ & $29 \pm 5.90$ & $15 \pm 6.3$ & $2685 \pm 1435$ & 53 \\
\hline $\mathrm{Al}$ & $124 \pm 219$ & $8111 \pm 5820$ & $373 \pm 298$ & $4506 \pm 2661$ \\
\hline $\mathrm{Ni}$ & $1 \pm 0.06$ & $7.5 \pm 4.8$ & $183 \pm 147$ & $6.5 \pm 2.7$ \\
\hline As & $1 \pm 0.13$ & $6.5 \pm 1.6$ & $1514 \pm 152$ & $9.4 \pm 4$ \\
\hline $\mathrm{Cd}$ & $0.13 \pm 0.14$ & $1.2 \pm 0.6$ & $351 \pm 357$ & $0.5 \pm 0.2$ \\
\hline $\mathrm{Ba}$ & $23 \pm 3.03$ & $100 \pm 53$ & $48 \pm 35$ & $15.3 \pm 5$ \\
\hline $\mathrm{Pb}$ & $0.8 \pm 0.53$ & $10 \pm 1.4$ & $2002 \pm 2041$ & $36 \pm 18$ \\
\hline $\mathrm{Cl}^{-}$ & $0.4 \pm 0.43^{b}$ & & $191 \pm 112^{b}$ & \\
\hline $\mathrm{Br}-$ & $0.36 \pm 0.70^{b}$ & & 150 & \\
\hline $\mathrm{PO}_{4}^{3-}$ & $5.77 \pm 3.05^{\mathrm{a}}$ & & 3.1 & \\
\hline $\mathrm{NO}_{3}^{-}$ & $45 \pm 7.36^{a}$ & & 6.9 & \\
\hline
\end{tabular}

the rainy season, the diversity of algae remained high, with a growing predominance of Coscinodiscus sp.

The phytoplankton of the Mocajuba estuary contained the highest concentrations of $\mathrm{Na}, \mathrm{K}, \mathrm{Ca}, \mathrm{Mg}, \mathrm{P}, \mathrm{Mn}, \mathrm{Fe}, \mathrm{Zn}$, and $\mathrm{Pb}$. In the Pará estuary, high concentrations were recorded only for $\mathrm{Fe}, \mathrm{Al}$, and $\mathrm{Ba}$ (Table 2). The high levels of $\mathrm{Al}, \mathrm{Fe}, \mathrm{K}, \mathrm{Ca}$, and $\mathrm{P}$ were confirmed by the energy dispersive spectroscopy (EDS) analyses of Actinocyclus normanii, Polymyxus coronalis, and Aulacoseira granulata (Table 3 and Figure 2).

In the Pará estuary (Figure 3A, C), significant positive correlations were found between the abundance of metals in the phytoplankton and the chemical composition of of the sediments and the water $\left(r^{2}=0.77\right.$ and 0.95 , respectively; 

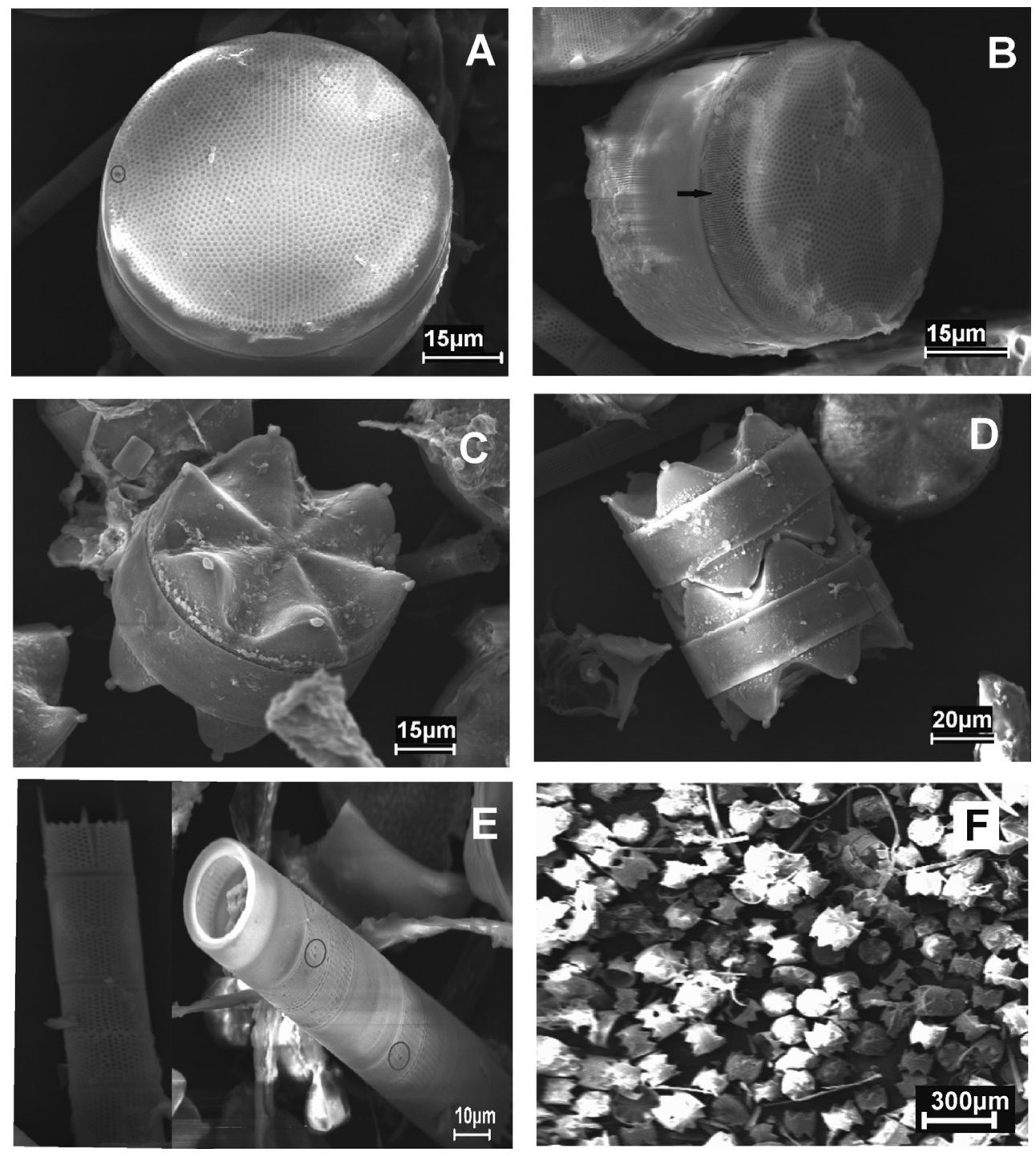

Figure 2. SEM image: Actinocyclus normanii (Gregory) Hustedt: (A) valvar view showing the pseudonodules and (B) valves with a distinct ring between the mantle and the valvar face; Polymyxus coronalis Bailey: (C) valvar view showing six elevated points and (D) valves agglomerated in colonies; Aulacoseira granulata (Ehrenberg) Simonsen: (E) lateral view of the colony showing the rimoportulae adjacent to the valvar face: (F) predominance of Polymyxus coronalis in the samples from the Pará estuary

Table 3. Chemical concentrations (means and standard deviations) of the elements $\mathrm{Na}, \mathrm{Mg}, \mathrm{K}, \mathrm{Ca}, \mathrm{P}, \mathrm{Fe}, \mathrm{Al}$ and Si $\left(\mu \mathrm{g} \mathrm{g^{-1 }}\right)$ analyzed in the diatoms of the Pará estuary by X-ray dispersion spectrometry (SED 500 DP)

\begin{tabular}{lcccccccc}
\hline Species & $\mathrm{Na}$ & $\mathrm{Mg}$ & $\mathrm{K}$ & $\mathrm{Ca}$ & $\mathrm{P}$ & $\mathrm{Fe}$ & $\mathrm{Al}$ & $\mathrm{Si}$ \\
\hline \multirow{2}{*}{ A. normanii } & 1766 & 382 & 610 & 732 & 1372 & 2070 & 6918 & 402332 \\
& \pm 333 & \pm 102 & \pm 385 & \pm 128 & \pm 199 & \pm 502 & \pm 1846 & \pm 22173 \\
P. coronalis & 1967 & 291 & 2357 & 1377 & 1510 & 7700 & 10759 & 535113 \\
& \pm 1755 & \pm 177 & \pm 1102 & \pm 1085 & \pm 438 & \pm 4436 & \pm 9348 & \pm 144911 \\
A. granulata & 773 & 298 & 2903 & 1931 & 1430 & 5006 & 6277 & 620058 \\
& \pm 731 & \pm 143 & \pm 1485 & \pm 758 & \pm 395 & \pm 2872 & \pm 2614 & \pm 143274 \\
\hline
\end{tabular}



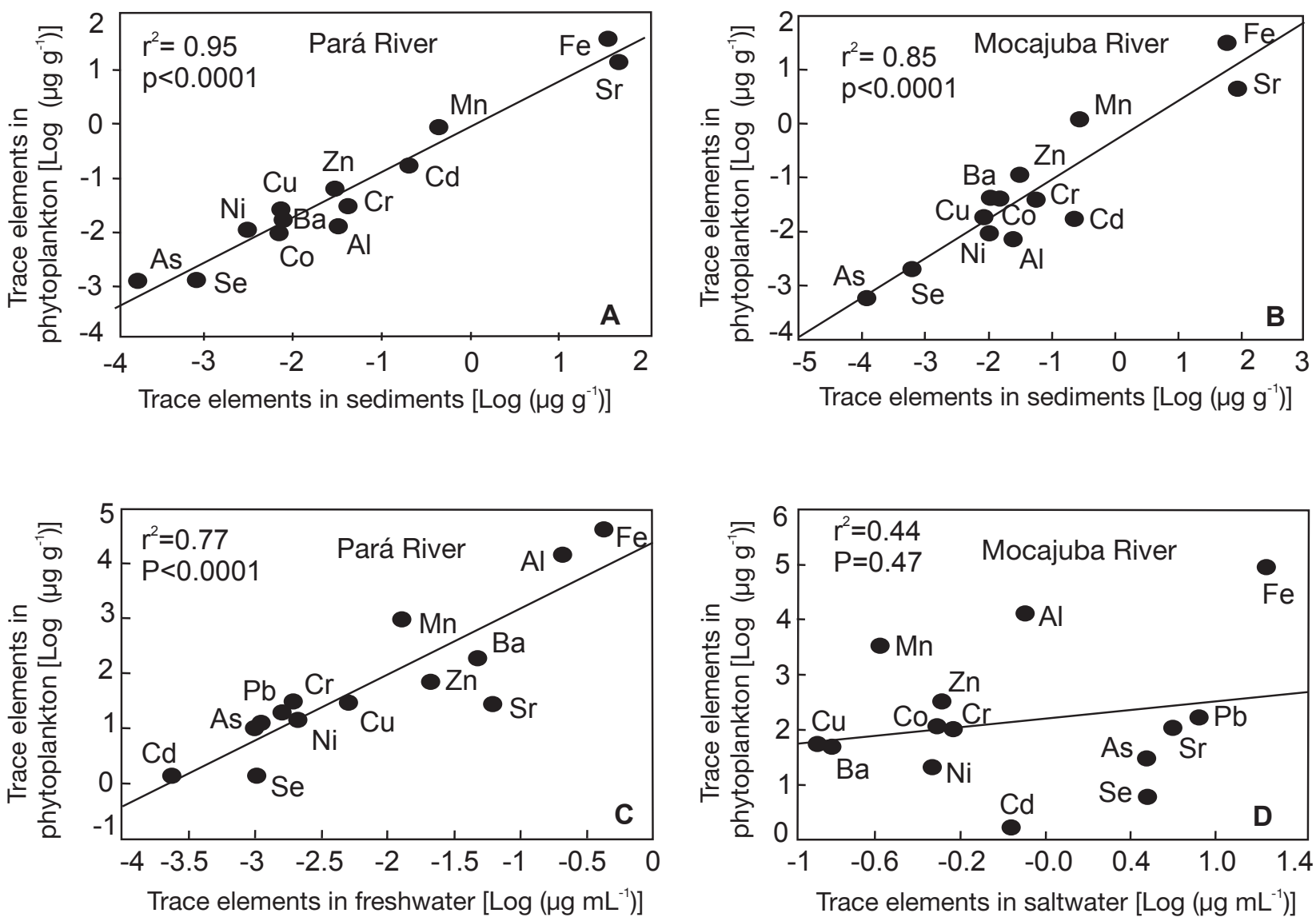

Figure 3. Correlations between the trace elements $\left(\mu \mathrm{g} \mathrm{L}^{-1}\right)$ recorded in the phytoplankton and the water (values in $\mu \mathrm{g} \mathrm{L}^{-1}$ normalized by the phosphates). Chemical composition of the phytoplankton and sediments $\left(\mu \mathrm{g} \mathrm{g}^{-1}\right)$ normalized by $\mathrm{P}$ in the Pará (A and $\mathrm{C}$ ) and Mocajuba (B and D) estuaries

Table 4. Synthesis of the main components PCoA of the chemical elements

\begin{tabular}{lcc}
\hline & Axis 1 & Axis 2 \\
\hline Auto value & 0.18 & 0.43 \\
Percentage of variance explained & 66.24 & 15.29 \\
Percentage of cumulative variance & 66.24 & 81.52 \\
Results of randomization "p" & 0.001 & 0.001 \\
\hline
\end{tabular}

$\mathrm{p}<0.001$ ) - as found by Quigg et al. (2003) and Libes (2009). In the Mocajuba estuary (Figure 3B, D), by contrast, the contribution of the water to the chemical composition of the phytoplankton appears to be much less $\left(r^{2}=0.44, p=0.47\right)$, with a strong correlation being found only with the chemical composition of the sediments $\left(\mathrm{r}^{2}=0.85, \mathrm{p}<0.001\right)$.

The principal coordinates analysis summarized approximately $81 \%$ of the combined variability of the data on the first two axes (Figure 4, Tables 4 and 5). The positive side of axis 1 contains all the values for the chemical composition of the water of the Pará estuary, while the negative side encompasses the remaining values (chemical composition of the phytoplankton, water, and sediment) associated primarily with the concentrations of $\mathrm{K}, \mathrm{Mg}, \mathrm{Ca}, \mathrm{Mn}, \mathrm{Co}, \mathrm{Se}, \mathrm{Ni}, \mathrm{As}, \mathrm{Cd}$, $\mathrm{Cr}, \mathrm{Cu}, \mathrm{Pb}$, and $\mathrm{Al}(\mathrm{r} \geq 0.05)$. The positive side of axis 2 groups the chemical concentrations of the water of the Mocajuba estuary, associated primarily with $\mathrm{Se}, \mathrm{Sr}, \mathrm{As}$, and $\mathrm{Cd}(\mathrm{r} \geq 0.03)$, and separating the phytoplankton and sediment samples.

\section{Bioconcentration factor (BCF)}

The highest $\mathrm{BCF}$ values were recorded in the phytoplankton from the Pará estuary for most chemical elements except $\mathrm{Zn}$ and $\mathrm{Pb}$, for which higher concentrations were recorded in the Mocajuba estuary (Table 6). The elements P, Mn, Fe, Al, and $\mathrm{Ba}$ generated the highest $\mathrm{BCF}$ values, although $\mathrm{Al}$ and $\mathrm{Ba}$ were found in low concentrations in the phytoplankton from the Mocajuba estuary. 


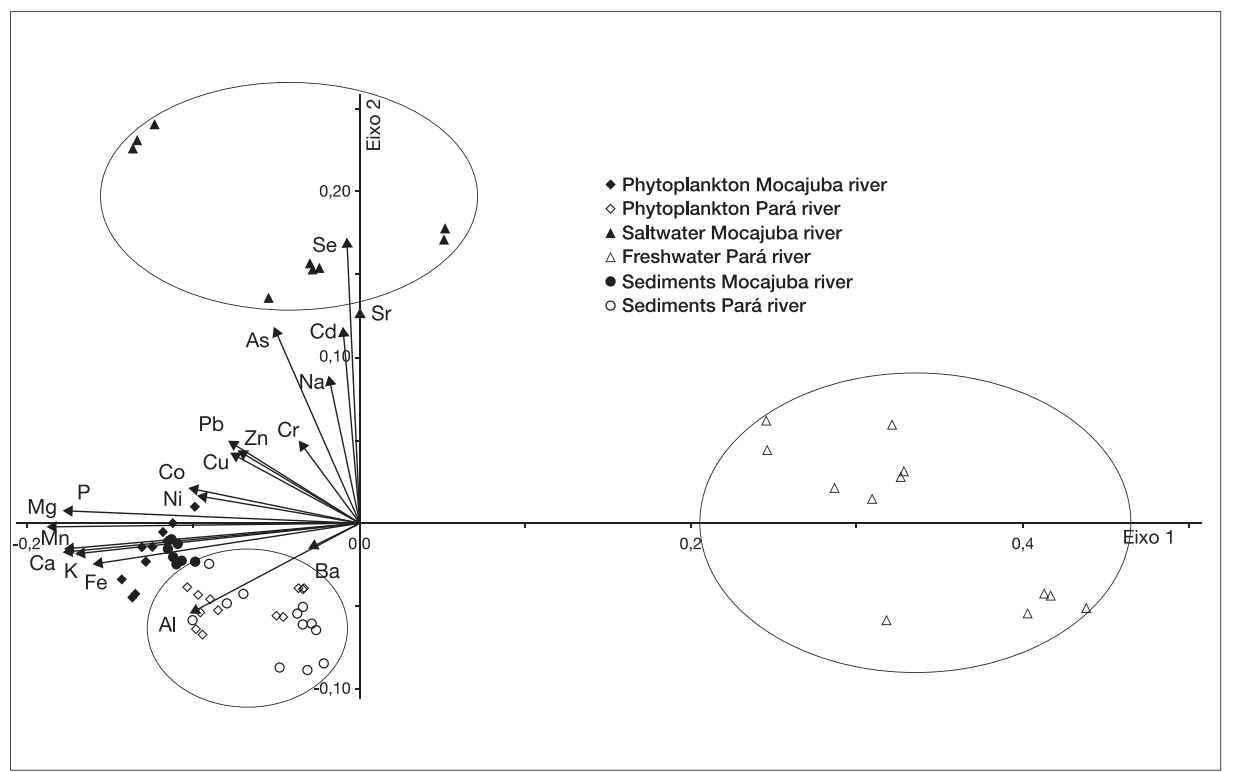

Figure 4. Principal coordinates analysis of the chemical elements in the Mocajuba and Pará Rivers (sediments. surface water and phytoplankton)
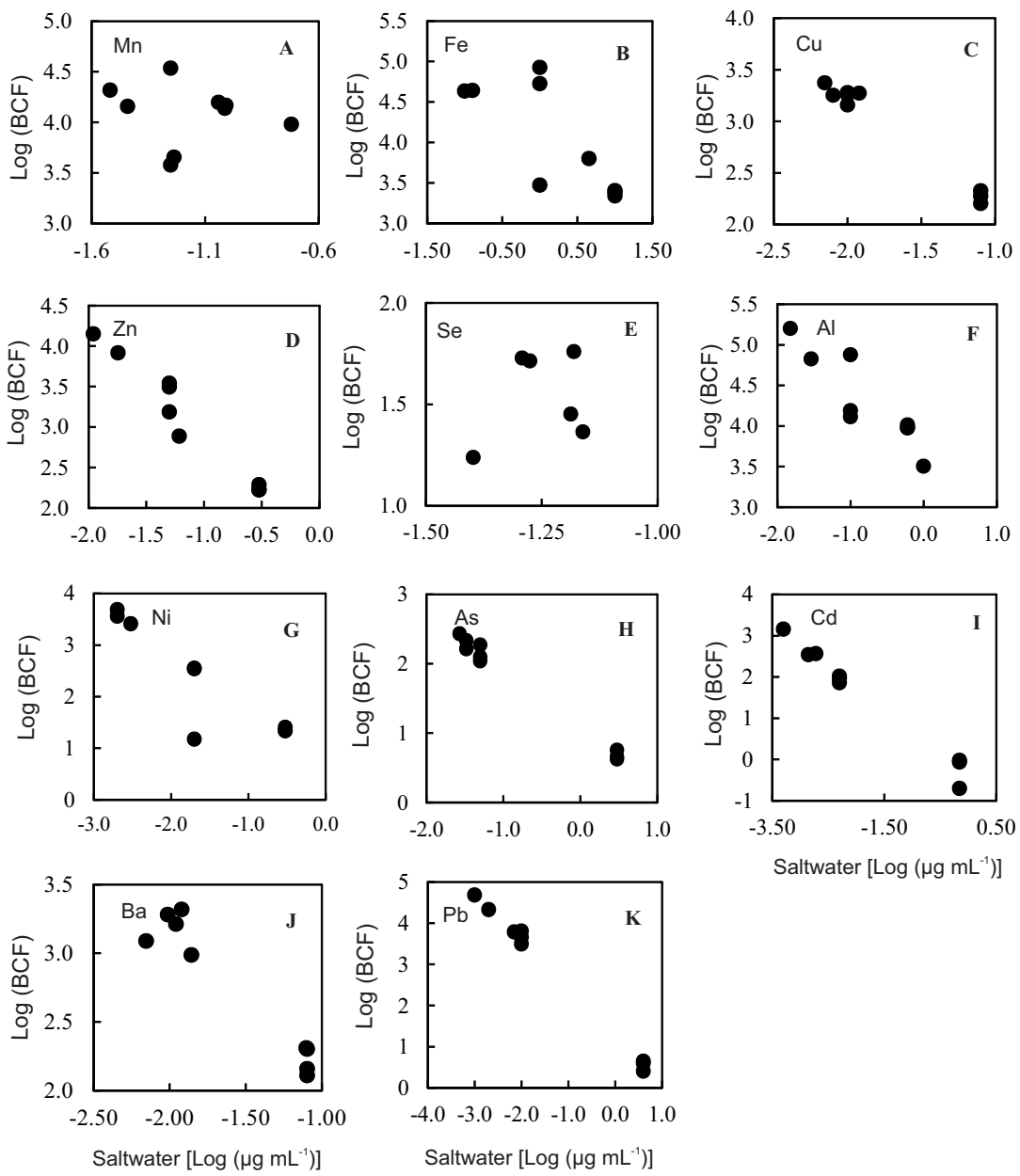

Figure 5. Correlations between the bioconcentration factor (BCF) of the phytoplankton and the trace elements $\left(\mu \mathrm{g} \mathrm{mL}^{-1}\right)$ in the waters of the Mocajuba estuary 
Table 5. Principal coordinates analysis (bold values are significant correlations)

\begin{tabular}{|c|c|c|c|c|c|}
\hline Variable & Axis 1 & Axis 2 & Variable & Axis 1 & Axis 2 \\
\hline $\mathrm{Na}$ & -0.01672 & 0.01727 & $\mathrm{Zn}$ & -0.03195 & 0.01186 \\
\hline K & -0.07226 & -0.1153 & Se & -0.05086 & 0.11193 \\
\hline $\mathrm{Mg}$ & -0.06917 & -0.00425 & $\mathrm{Sr}$ & 0.00523 & 0.03959 \\
\hline $\mathrm{Ca}$ & -0.06189 & -0.00948 & Al & -0.04152 & -0.01451 \\
\hline$P$ & -0.03699 & 0.00391 & $\mathrm{Ni}$ & -0.06256 & 0.01250 \\
\hline $\mathrm{Mn}$ & $\begin{array}{l}-0.04924 \\
-0.05842\end{array}$ & -0.00850 & As & -0.06880 & 0.04987 \\
\hline $\mathrm{Fe}$ & -0.03744 & -0.00718 & $\mathrm{Cd}$ & -0.08319 & 0.13183 \\
\hline Co & -0.09531 & 0.02109 & $\mathrm{Ba}$ & -0.01739 & -0.00587 \\
\hline $\mathrm{Cu}$ & -0.04350 & 0.01534 & $\mathrm{~Pb}$ & -0.07662 & 0.02909 \\
\hline
\end{tabular}
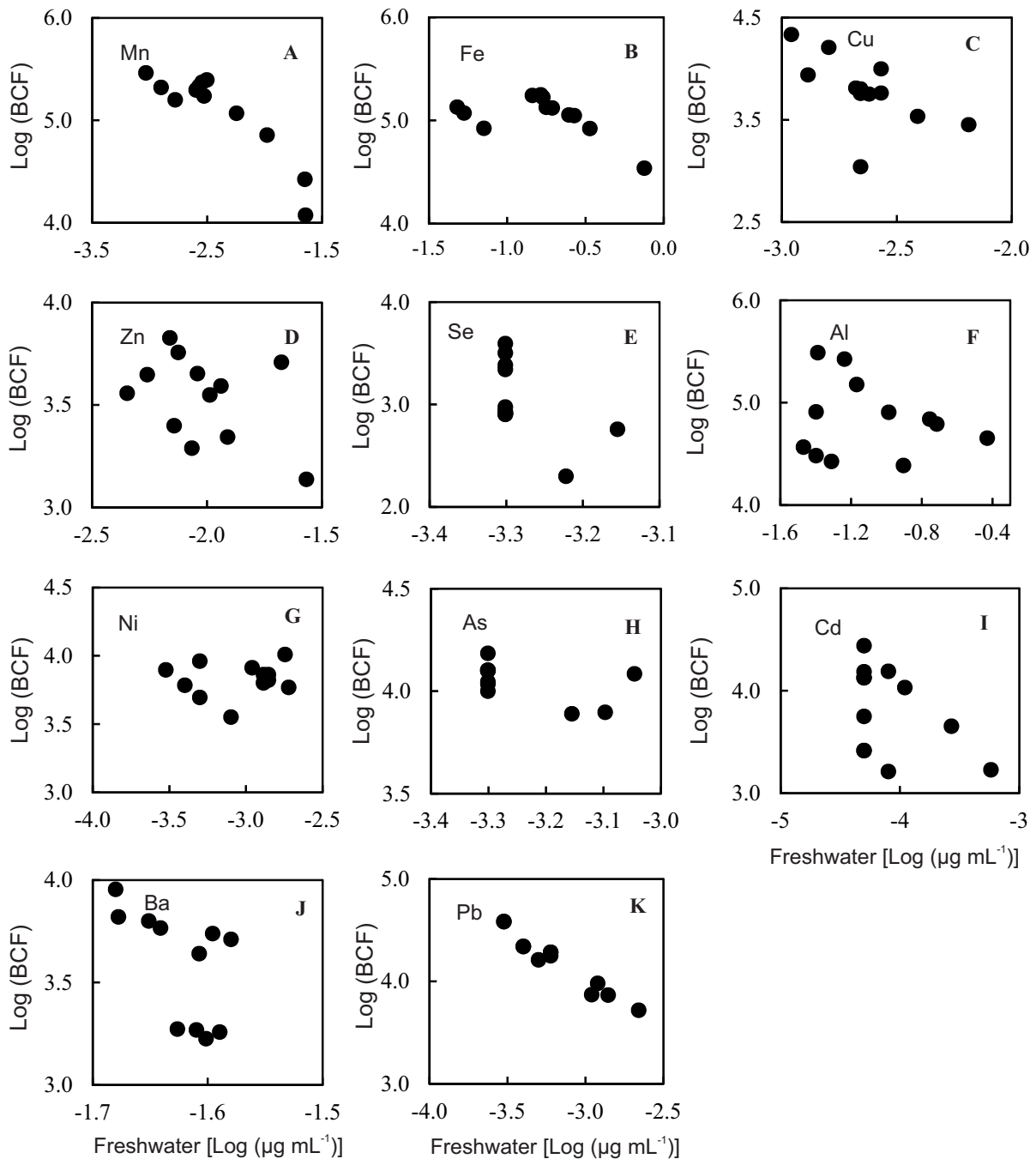

Figure 6. Correlations between the bioconcentration factor (BCF) of the phytoplankton and the trace elements $\left(\mu \mathrm{g} \mathrm{mL}^{-1}\right)$ in the waters of the Pará estuary 
Table 6. Regression analyses of the concentrations of chemical elements $\log$ BCF values and the chemical concentrations of the water $\left(\mu \mathrm{g} \mathrm{mL}{ }^{-1}\right)$ and the minimum, maximum and mean BCF values for the Pará and Mocajuba estuaries (BCF denotes bioconcentration factor). FW (denotes freshwater); SW (denotes saltwater); $n=12$ (phytoplankton Pará River), $n=10$ (phytoplankton Mocajuba River); $r^{2}$, coefficient determination; $r^{2}$ to the level of significance * $p<0.05$; ${ }^{* *} p<0.01 ;{ }^{* *} p<0.001 ;$ ns, not significant.

\begin{tabular}{|c|c|c|c|c|c|c|c|c|}
\hline & \multirow{2}{*}{ Water type } & \multicolumn{4}{|c|}{$\begin{array}{l}\text { Regression coefficients for log-linear relationship between BCF water } \\
\text { conc. (log:log scale). }\end{array}$} & \multicolumn{3}{|c|}{ Empirical BCFs } \\
\hline & & Slope & Intercept & $\mathrm{R}^{2}$ & $\mathrm{p}$-Valor & Minimum & Mean & Máximum \\
\hline \multirow[t]{2}{*}{ K } & FW & 2.925 & -0.194 & 0.004 & $0.82 \mathrm{~ns}$ & 366 & 847 & 1,297 \\
\hline & SW & 3.428 & -1.050 & 0.79 & $0.001^{* * *}$ & 10 & 17.04 & 30 \\
\hline \multirow[t]{2}{*}{$\mathrm{Mg}$} & FW & 2.551 & -0.146 & 0.003 & $0.85 \mathrm{~ns}$ & 318 & 699 & 1,107 \\
\hline & SW & 5.338 & -1.489 & 0.65 & 0.008 ** & 2 & 6 & 16 \\
\hline \multirow[t]{2}{*}{$\mathrm{Ca}$} & FW & 3.015 & -0.326 & 0.04 & $0.516 \mathrm{~ns}$ & 126 & 479 & 1,786 \\
\hline & SW & 2.704 & -0.938 & 0.08 & 0.45 & 17 & 31 & 88 \\
\hline \multirow[t]{2}{*}{$P$} & FW & 3.156 & -0.761 & 0.43 & 0.01 * & 6,217 & 16,2527 & 289,818 \\
\hline & SW & 3.321 & -0.943 & 0.98 & $>0.001^{* * *}$ & 521 & 3,488 & 11,712 \\
\hline \multirow[t]{2}{*}{$\mathrm{Mn}$} & FW & 3.00 & -0.864 & 0.82 & $>0.001^{* \star *}$ & 11,843 & 162,527 & 289,818 \\
\hline & SW & 3.893 & -0.161 & 0.017 & $0.73 \mathrm{~ns}$ & 3,785 & 14,618 & 34,230 \\
\hline \multirow[t]{2}{*}{$\mathrm{Fe}$} & FW & 4.818 & -0.301 & 0.27 & 0.07 & 34,493 & 121,908 & 177,108 \\
\hline & SW & 4.168 & -0.669 & 0.59 & $0.01 *$ & 2,189 & 26,814 & 84,750 \\
\hline \multirow[t]{2}{*}{$\mathrm{Cu}$} & FW & 1.120 & -1.009 & 0.36 & 0.03 * & 1,097 & 7,802 & 21,581 \\
\hline & SW & 1.115 & -1.058 & 0.98 & $>0.001^{* * *}$ & 159 & 1,306 & 2,361 \\
\hline \multirow[t]{2}{*}{$\mathrm{Zn}$} & FW & 2.774 & -0.378 & 0.17 & 0.183 & 1,369 & 3,796 & 6,718 \\
\hline & SW & 1.533 & -1.358 & 0.95 & $0.003 * * *$ & 166 & 3,538 & 14,187 \\
\hline \multirow[t]{2}{*}{ Se } & FW & -10.84 & -4.229 & 0.28 & 0.07 & 199 & 1,460 & 3,921 \\
\hline & SW & 0.070 & -0.172 & 0.94 & $>0.001^{* \star *}$ & 0.18 & 26 & 58 \\
\hline \multirow[t]{2}{*}{$\mathrm{Al}$} & FW & 4.623 & -0.195 & 0.03 & $0.581 \mathrm{~ns}$ & 24,392 & 98,156 & 306,788 \\
\hline & SW & 3.706 & -0.75 & 0.80 & 0.001 ** & 3,503 & 40,390 & 159,660 \\
\hline \multirow[t]{2}{*}{$\mathrm{Ni}$} & FW & 4.000 & 0.57 & 0.01 & $0.69 \mathrm{~ns}$ & 3,552 & 6,948 & 10,224 \\
\hline & SW & 0.685 & -1.018 & 0.80 & $>0.001^{* * *}$ & 15 & 1,318 & 4,854 \\
\hline \multirow[t]{2}{*}{ As } & FW & 2.461 & -0.489 & 0.27 & 0.07 & 8,327 & 10,455 & 18,220 \\
\hline & SW & 1.070 & -0.827 & 0.98 & $>0.001^{* * *}$ & 4 & 121 & 271 \\
\hline \multirow[t]{2}{*}{$\mathrm{Cd}$} & FW & 1.619 & -0.536 & 0.19 & $0.151 \mathrm{~ns}$ & 7,756 & 11,497 & 15,272 \\
\hline & SW & -0.439 & -1.063 & 0.97 & $>0.001^{* * *}$ & 0.39 & 269 & 1,442 \\
\hline \multirow[t]{2}{*}{$\mathrm{Ba}$} & FW & 1.085 & -975 & 0.46 & 0.01 * & 1,326 & 4,273 & 8,999 \\
\hline & SW & 1.075 & -1.055 & 0.92 & $>0.001^{* * *}$ & 129 & 944 & 2,082 \\
\hline \multirow[t]{2}{*}{$\mathrm{Pb}$} & FW & 1.085 & -0.975 & 0.94 & $>0.001^{* * *}$ & 5,223 & 18,524 & 38,300 \\
\hline & SW & 1.268 & -1.162 & 0.99 & $>0.001 * * \star$ & 2.6 & 10,000 & 48,338 \\
\hline
\end{tabular}

Significant inverse relationships $(\mathrm{p}<0.005)$ were found between the BCF values and the concentrations of most chemicals in the waters of the Mocajuba estuary (Table 6), except for Mn (Figure 5). In the Pará estuary, significant inverse relationships $(\mathrm{p}<0.05)$ were obtained only for $\mathrm{Mn}$, $\mathrm{Cu}, \mathrm{Ba}$, and $\mathrm{Pb}$ (Figure 6). Previous studies of a number of different organisms (Kenaga 1980; McGeer et al. 2003) have also recorded an inverse relationship between the BCF and the chemical composition of the water.

The bioconcentration factors - obtained for the sediments (BSCF) by dividing the total sample by the bio-available fraction - were high for all the trace elements in both estuaries. 

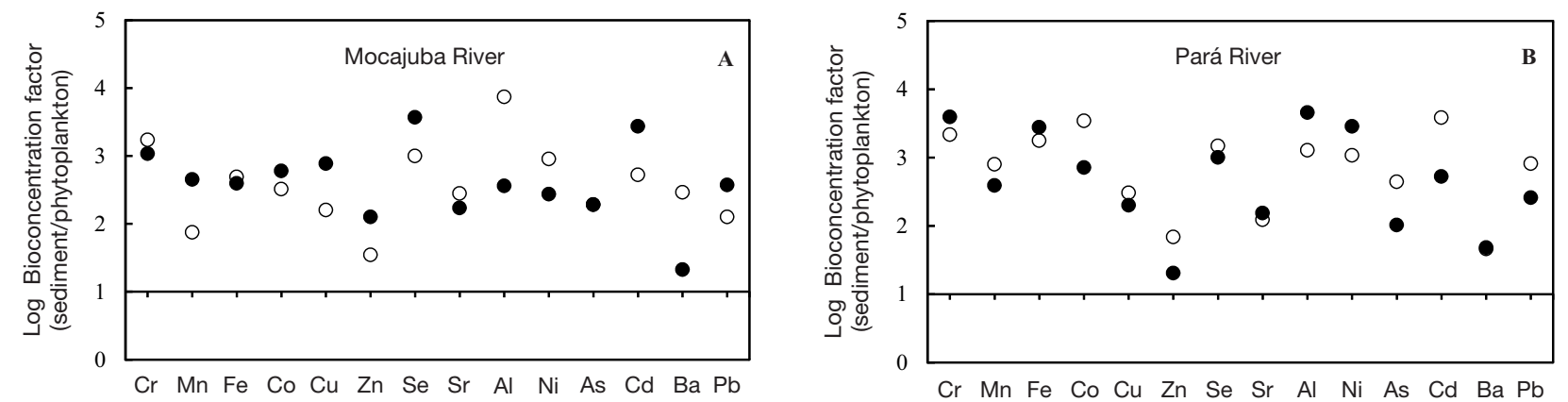

Figure 7. Bioaccumulation factors (total sediment/bioavailable fraction) for the bottom sediments (O) and the phytoplankton (•) (phytoplankton/bioavailable fraction)

The variation in $\mathrm{Al}$ and $\mathrm{Ba}$ was highest in the Mocajuba estuary, and variation in $\mathrm{Cd}$ was highest in the Pará estuary (Figure 7). The phtyoplankton:bioavailable fraction ratio was highest for Se and Cd in the Mocajuba estuary, and for Cr, $\mathrm{Fe}, \mathrm{Al}$, and $\mathrm{Ni}$ in the Pará estuary. Similar relationships were observed between $\mathrm{Cr}, \mathrm{Fe}, \mathrm{Co}, \mathrm{Cu}, \mathrm{Se}$, and $\mathrm{Sr}$ and the sediment ratios and the phtyoplankton:bioavailable ratio, with some degree of variation. It seems likely that these elements were absorbed in more or less the same proportions. However, the phytoplankton in the Mocajuba estuary concentrated $\mathrm{Al}, \mathrm{Ni}$, and $\mathrm{Ba}$ at low rates, and $\mathrm{Mn}, \mathrm{Cu}, \mathrm{Zn}, \mathrm{Se}, \mathrm{Cd}$, and $\mathrm{Pb}$ in excess.

\section{DISCUSSION}

The high concentrations of $\mathrm{Na}, \mathrm{K}, \mathrm{Ca}, \mathrm{Mg}, \mathrm{Fe}, \mathrm{Zn}, \mathrm{Al}$, $\mathrm{Ba}$, and $\mathrm{Pb}$ in the chemical composition of the phytoplankton collected from the two estuaries probably reflects the availability of these elements in the water and the sediments, in addition to the influence of oceanic waters. Fe and $\mathrm{Al}$, the most concentrated elements in the Pará estuary, are strong indicators of the contribution of matter derived from the soil around the margins of the estuary, which are dominated by sediments rich in iron oxy-hydroxides (goethite and hematite) as well as aluminosilicates. The high levels of AL may also be influenced by aluminum of anthropogenic origin.

These elements are generally concentrated at high levels in the phytoplankton in comparison to the results of previous studies (Admiral et al. 1995; Fitzwater et al. 2000; Bu-Olayana et al. 2001), with the exception of As and Pb. Our results are similar to those of Ho et al. (2003) and Martins and Knauer (1973) for phytoplankton from natural environments. The occurrence of Aulacoseira granulata is associated with eutrophized environments, and Aulacoseira is one of the 60 genera most tolerant of organic or industrial pollution (Palmer 1969; Reynolds 1998). However, while this species predominates in the Pará estuary, the high concentrations of $\mathrm{H}_{4} \mathrm{SiO}_{4}>\mathrm{NO}_{3}>\mathrm{PO}_{4}^{3-}$ in the water reflect a lack of major alterations of the environment.
The strong association observed between the chemical composition of the phytoplankton and the water and sediments of the Pará estuary may be related to the adsorption of metals by the iron oxy-hydroxides precipitated on the surface of the cells of the phytoplankton, particularly diatoms (Sunda and Huntsman 1995; 2000). In the Mocajuba estuary, the biogeochemical processes of oxide-reduction that control the environment (Sunda and Huntsman 1998) are probably responsible for the low correlation found between the chemistry of the phytoplankton and that of the water. The significant association found with the chemical composition of the sediments may be related to the precipitation of sulfides on the surface of the phytoplankton, which adsorb metals, in particular Fe (Maldonado and Price 1999).

The adsorption process probably resulted in the overestimation of the concentrations of a number of trace metals, in addition to $\mathrm{Fe}$ (Takeda 1998; Haritonidis and Malea 1999; Hutchins et al. 1999). The adsorption mechanism may account for the enrichment of $\mathrm{Mn}, \mathrm{Co}, \mathrm{Zn}, \mathrm{As}, \mathrm{Cd}$, and $\mathrm{Pb}$ recorded in the phytoplankton from the Mocajuba estuary, and that of $\mathrm{Mg}, \mathrm{Fe}$, and $\mathrm{Al}$ in the Pará.

There was a strong relationship between the high levels of $\mathrm{Mn}, \mathrm{Fe}, \mathrm{Cu}, \mathrm{Zn}, \mathrm{Se}, \mathrm{Sr}, \mathrm{Cd}$, and $\mathrm{Pb}$ found in the phytoplankton from the Mocajuba and the bioavailable fraction, with a similar pattern being found in the Pará for $\mathrm{Cr}, \mathrm{Fe}, \mathrm{Al}$, and $\mathrm{Ni}$. The interactions among the chemical composition of the sediment, the bioavailable fraction, and the water play an essential role in phytoplankton productivity (Valenta et al. 1986; Jensen et al. 1982; Wang and Dei 2001).

The multivariate analysis confirmed that the waters of the Mocajuba and Pará estuaries constitute two chemically distinct environments, with a clear separation of the chemical composition of the sediments and phytoplankton. The phytoplankton and sediments had the greatest chemical affinity, in particular with respect to $\mathrm{Al}$, which was strongly correlated with the sediment and phytoplankton samples from the Pará estuary. Aluminum is transported by physical or chemical processes and is rapidly absorbed by phytoplankton 
due to its large surface area and volume, reaching extremely high concentration factors (Fisher and Reinfelder 1995). It does not appear, however, that the high levels of $\mathrm{Al}$ present in the phytoplankton of the Pará estuary are derived from the sediments because of the low levels of clay minerals $(<7 \%)$ in this region. In this case, the high $\mathrm{Al}$ concentrations are probably associated with the discharge of domestic effluents and industrial waste into the estuary.

The high BCF values recorded for the elements $\mathrm{Mn}$, $\mathrm{Fe}, \mathrm{Al}, \mathrm{Ni}, \mathrm{As}, \mathrm{Cd}$, and $\mathrm{Pb}$ emphasize the capacity of the phytoplankton to bioaccumulate metals (Martin and Knauer 1973). The adsorption of metals is well understood in phytoplankton (French and Evans 1988; Franklin et al. 2002), and has been demonstrated in a number of studies (MorenoGarrido et al. 2000; Nayar et al. 2004; Tien 2004). Diatoms, in particular, may be tolerant of heavy metals (Seidl et al. 1998; French and Evans 1988), especially copper, an excess of which may cause teratological formations in the frustule, in addition to a reduction in the production of phytoplankton and chlorophyll (Balczon and Pratt 1994; Viana and Rocha 2005). High Al concentrations inhibit the adsorption and physiological processing of phosphorus in the phytoplankton (Barabasz et al. 2002).

The observed $\mathrm{BCF}$ values are higher than those recorded in diatoms for $\mathrm{Zn}$ (Harvey and Patrick 1967), and those recorded in green algae for $\mathrm{Pb}, \mathrm{Cd}, \mathrm{Cr}$, and $\mathrm{Zn}$ (Becker 1983). Three significant inverse relationships $(P<0.005)$ were found between the BCF and the chemical composition of the waters of the Mocajuba and Pará estuaries, indicating that the phytoplankton is capable of removing and detoxifying these elements in order to maintain low intracellular levels even when the environmental concentrations are high (Wood and Wang 1983). Similar results were obtained by Sigee et al. (1988) in a comparison of BCF and the chemical composition of the water. The lack of an inverse relationship between $\mathrm{Ni}$ and $\mathrm{Al}$, and the reduced relationships recorded for most other elements in the Pará estuary (Figure 6) may reflect the capacity of phytoplankton to bioaccumulate and store these elements at a rate proportional to their adsorption (Trollope and Evans 1976).

The $\mathrm{BSCF}$ values recorded for $\mathrm{Al}$ and $\mathrm{Ba}$ indicate that these elements are poorly assimilated by the phytoplankton of the Mocajuba estuary (Figure 7A). However, even low BCF and BSCF values indicate that the phytoplankton has an enhanced capacity for the accumulation of bioavailable elements, and may therefore be good indicators of contamination (Franklin et al. 2002).

\section{CONCLUSIONS}

The phytoplankton of the study areas concentrate high levels of $\mathrm{Ca}, \mathrm{P}, \mathrm{Mn}, \mathrm{Fe}, \mathrm{Zn}, \mathrm{Al}$, and $\mathrm{Ba}$, reflecting both the natural characteristics of the environment and the anthropogenic inputs. In particular, the high $\mathrm{Al}$ levels found in the phytoplankton of the more polluted Pará estuary. The high concentrations of the chemical elements, and the high bioconcentration values (BCF and BSCF) between the phytoplankton, water, and the bioavailable fraction indicate that the phytoplankton have an enormous capacity for the accumulation of trace metals, and are thus potentially excellent bioindicators for the evaluation of the contamination of Amazonian ecosystems by metals.

\section{ACKNOWLEDGMENTS}

The authors are grateful to Conselho Nacional de Desenvolvimento Científico e Tecnológico, CNPq for awarding a scholarship to the first author, and also a

productivity scholarship to the second author. The Museu Paraense Emílio Goeldi, Coordenação de Ciências da Terra e Ecologia provided infrastructure and we thank the Center for Nuclear Energy in Agriculture, Laboratory of Environmental Analysis and GIS. Thanks also to Prof. R.J. Ladle (UFAL \& Oxford University) for revising the text

\section{REFERENCES}

Admiraal, W.; Tubbing, G.M.J.; Breebaart, L. 1995. Effects of phytoplankton on metal partitioning in the lower River Rhine. Water Research, 29: 941-946.

Balczon, J.M.; Pratt, J.R. 1994. A comparison of the responses of two microcosm designs to a toxic input of copper. Hydrobiologia, 281: 101-114.

Barabasz, W.; Albińska, D.; Jaśkowska, M.; Lipiec, J. 2002. Ecotoxicology of Aluminium. Polish Journal of Environmental Studies, 11: 199-203.

Becker, E.W. 1983. Limitations of heavy metal removal from waste water by means of algae. Water Research, 17: 459-66.

Bruland, K.W.; Donat, J.R.; Hutchins, D.A. 1991. Interactive influences of bioactive trace metals on biological production in oceanic waters. Limnology Oceanography, 36: 1555-1577.

Bu-Olayan, A.H.; Al-Hassan, R.; Thomas, B.V.; Subrahmanyam, M.N.V. 2001. Impact of trace metals and nutrients levels on phytoplankton from the Kuwait Coast. Environment International, 26: 199-203.

Costa, M.L.; Behling, H.; Berrêdo, J.F.; Siqueira, N.V.M. 2004. Mineralogical, Geochemical and Palynological Studies of Late Holocene Mangrove Sediments from Northeastern Para State, Brazil. Revista Brasileira de Geociências, 34: 479-488.

Figueiras, F.G.; Pazos, Y. 1991. Microplankton assemblages in three Rías Baixas Vigo, Arosa and Muros, Spain with a subsurface chlorophyll maximum: their relationships to hydrography. Marine Ecology Progress Series, 76: 219-233.

Fisher, N. S.; Reinfelder, J. R. 1995. The trophic transfer of metals in marine systems. In: Tessier, A.; Turner, D. R. (eds.) Metal speciation and bioavailability in aquatic systems. Wiley: p. 363-406. 
Fitzwater, S.E.; Johnson, K.S.; Gordon, R.M.; Coale, K.H.; Smith Jr, W.O. 2000. Trace metal concentrations in the Ross Sea and their relationship with nutrients and phytoplankton growth. Deep-Sea Research II, 47: 3159-3179.

Franklin, N.M.; Stauber, J.L.; Apte, S.C.; Lim, R.P. 2002. Effect of initial cell density on the bioavailability and toxicity of copper in microalgal bioassays. Environmental Toxicology Chemistry, 21: 742-751.

French, M.S.; Evans, L.V. 1988. The effects of copper and zinc on the growth of the fouling diatoms Amphora and Amphiprora. Biofouling, 1: 3-18.

Furuya, K. 1990. Subsurface chlorophyll maximum in the tropical and subtropical western Pacific Ocean: vertical profiles of phytoplankton biomass and its relationship with chlorophyll a and particulate organic carbon. Marine Biology, 107: 529-539.

González-Dávila, M. 1995. The role of phytoplankton cells on the control of heavy metal concentration in seawater. Marine Chemistry, 48: 215-236.

Haritonidis, S.; Malea, P. 1999. Bioaccumulation of metals by the green alga Ulva rigida from Thermaikos Gulf, Greece. Environmental Pollution, 104: 365-372.

Harvey, R.S.; Partick R. 1967. Concentrations of Cs, Zn and Sr by freshwater algae. Biotech Bioeng, 9: 449-56.

Ho, T.Y.; Finkel, A.Q.Z.V.; Milligan, A.J.; Wyman, K.; Falkowski, P.G. 2003. The elemental composition of some marine phytoplankton. Jounal of Phycology, 39: 1145-1159.

Hutchins, D.A.; Witter, A.E.; Butler, A.; Luther, G.W. 1999. Competition among marine phytoplankton for different chelated iron species. Nature, 400: 858-61.

Jensen, T.E.; Baxter, M.; Rachlin, J.W.; Jani, V. 1982. Uptake of heavy metals by Plectonema boryanum (Cyanophyceae) into cellular components, especially polyphosphate: an Xray energy dispersive study. Environmental Pollution, 27: 119-27.

Kenaga, E.E. 1980. Correlation of bioconcentration factors of chemicals in aquatic and terrestrial organisms with their physical and chemical properties. Environmental Science Technology, 14: 553-556.

Kjerfve, B.; Lacerda, L.D. 1993. Mangroves of Brazil. In: Lacerda, L.D. (ed.) Conservation and Sustainable Utilization of Mangrove Forests in Latin America and Africa Regions. International society mangrove ecosystems: p. 245-272.

Leynaert, A.; Tréguer, P.; Quéguiner, B.; Morvan, J. 1991. The distribution of biogenic silica and the composition of particulate organic matter in the Weddell-Scotia sea during spring 1988. Marine Chemistry, 35: 435-447.

Libes, S.M. 2009. Introduction to marine biogeochemistry, Academic Press, 765p.

Luoma, S.N.; Van Geen, A.; Lee, B.-G.; Cloern, J.E. 1998. Metal uptake by phytoplankton during a bloom in South San Francisco Bay: implications for metal cycling in estuaries. Limnology Oceanography, 43: 1007-1016.

Macedo, E.G.; Santos Filho, B.; Potiguara, R.C.V.; Santos, D.S.B. 2005. Leaf Anatomy and Architecture of Montrichardialinifera (Arruda) Schott (Araceae) a Specie from Amazon Floodplain. Boletin Museu Paraense Emílio Goeldi, série Ciências Naturais, 1: 19-43.
Magdaleno, A.; Gomez, C.E.; Velez, C.G.; Accorinti, J. 1997. Preliminary toxicity tests using the green alga, Ankistrodesmus falcatus. Environmental Toxicology Water Quality, 12: 11-14.

Maldonado, M.T.; Price, N.M. 1999. Utilization of iron bound to strong organic ligands by plankton communities in the subarctic Pacific Ocean. Deep-Sea Research II, 46: 2447-73.

Martin, J.H.; Knauer, G.A. 1973. The elemental composition of plankton. Geochemica et Cosmochimica Acta, 37: 1639-1653.

McCune, B.M.J.; Mefford, M.J. 2011. PC-ORD Multivariate analysis of ecological data. Version 6.0 MJM. Software design, Oregon.

McGeer, J.C.; Brix, K.V.; Skeaff, J.M.; Deforest, D. K.; Brigham, S.I.; Adams, W. J.; Green, A. 2003. Inverse relationship between bioconcentration factor and exposure concentration for metals: Implications for hazard assessment of metals in the aquatic environment. Environmental Toxicology and Chemistry, 22: 1017-1037.

Moreno-Garrido, I.; Lubian, L.M.; Soares, A.M.V.M. 2000. Influence of cellular density on determination of EC50 in microalgal growth inhibition tests. Ecotoxicology Environmental Safety, 47: 112-116.

Nayar, S.; Goh, B.P.L.; Chou, L.M. 2004. Environmental impact of heavy metals from dredged and resuspended sediments on phytoplankton and bacteria assessed in situ mesocosms. Ecotoxicology and Environmental Safety, 59: 349-369.

Paiva, R.S.; Eskinazi-Leça, E.; Passavante, J.Z.O.; Silva-Cunha, M.G.G.; Melo, N.F.A.C. 2006. Ecological considerations on phytoplankton from the Guajará bay and from the Guamá river estuary in Pará, Brazil. Boletim Museu Paraense Emílio Goeldi. Ciências Naturais, 1: 133-146.

Palmer, C.M. 1969. A Composite Rating of Algae Toleranting Organic Pollution. Journal of Phycology, 5: 78-82.

Petersen, S.; Gustavson, K. 1996. Replacement of the medium for a natural phytoplankton community by tangential flow filtration with special emphasis on toxicity tests. Environmental Contamination Toxicology, 57: 603-609.

Quigg, A.; Finkel, Z.V.; Irwin, A.J.; Rosenthal, Y.; Ho, T.-Y.; Reinfelder, J.R. 2003. The evolutionary inheritance of elemental stoichiometry in marine phytoplankton. Nature, 425: 291-4.

Reynolds, C.S. 1998. What factors influence the species composition to phytoplankton in lakes of different trophic status? Hydrobiologia, 369/370: 11-26.

Seidl, M.; Huang, V.; Mouchela, J.M. 1998. Toxicity of combined sewer overflows on river phytoplankton: the role of heavy metals. Environmental Pollution, 101: 107-116.

Sigee, D.C.; Krivtsov, V.; Bellinger, E.G. 1998. Elemental concentrations, correlations and ratios in micropopulations of Ceratium hirundinella (Pyrrhophyta): anX-ray microanalytical study. European Journal Phycology, 33: 55-164.

Silva, C.A.; Souza-Filho, P.W.M.; Rodrigues, S.W.P. 2009. Morphology and modern sedimentary deposits of the macrotidal Marapanim Estuary (Amazon, Brazil). Continental ShelfResearch, 29: 619-631. 
Sunda, W.G.; Huntsman, S.A. 2000. Effect of Zn, Mn and Fe on $\mathrm{Cd}$ accumulation in phytoplankton: implications for oceanic $\mathrm{Cd}$ cycling. Limnology Oceanography, 45: 1501-1516.

Sunda, W.G.; Huntsman, S.A. 1998. Processes regulating cellular metal accumulation and physiological effects: Phytoplankton as model systems. The Science of the Total Environment, 219: 165-181

Sunda, W.G.; Huntsman, S.A. 1995. Iron uptake and growth limitation in oceanic and coastal phytoplankton. Marine Chemistry, 50: 189-206.

Takeda, S. 1998. Influence of iron availability on nutrient consumption ratio of diatoms in oceanic waters. Nature, 393: 774-777.

Taylor, S. R.; McLennan, S.M. 1985. The Continental Crust: Its Composition and Evolution. Blackwell, Oxford, 312 p.

Tien, C. 2004. Some aspects of water quality ina polluted lowland river in relation to the intracellular chemical levels in planktonic and epilithic diatoms. Water Research, 38: 1779-1790.

Trollope, D.R.; Evans, B. 1976. Concentrations of copper, iron, lead, nickel and zinc in freshwater algal blooms. Environmental Pollution, 11: 109-116.
Utermöhl, H. 1958. Zur vervollkomung der quantitativen methodik. Mitteilungen der Internationale Vereinigung für Teoretische and Angewandte. Limnologie, 9: 1-38.

Valenta, P.; Duursma, E.K.; Merks, A.G.A.; Riitzel, H.; Niirnberg, H.W. 1986 Distribution of Cd, $\mathrm{Pb}$ and $\mathrm{Cu}$ between the dissolved and particulate phase in the eastern Scheldt and western Scheldt estuary. Science of the Total Environment, 53: 41-76.

Viana, S.M.; Rocha, O. 2005. The toxicity of copper sulphate and atrazine to the diatom Aulacoseira granulata (Ehrenberg) Simmons. Acta Limnologica Brasiliensia, 17: 291-300.

Viarengo, A. 1985. Biochemical effects of trace metals. Marine Pollution, 16: 153-158.

Wang, W-X.; Dei, R.C.H. 2001. Influences of phosphate and silicate on $\mathrm{Cr}(\mathrm{VI})$ and $\mathrm{Se}(\mathrm{IV})$ accumulation in marine phytoplankton. Aquatic Toxicology, 52:39-47.

Wood, J.M.; Wang, H. 1983. Microbial resistance to heavy metals. Environmental Science \& Technology, 17: 582-590.

Recebido em 26/10/2013

Aceito em 26/03/2014 